\title{
Sustainable operations management: a typological approach
}

\author{
Lawrence M. Corbett \\ Victoria University of Wellington (New Zealand) \\ lawrence.corbett@vum.ac.nz
}

Received September 2008

Accepted April 2009

\begin{abstract}
This paper discusses the nature of sustainability and sustainable development as they relate to operations management. It proposes a typology for sustainable operations management that is based on the life cycle stages of a product and the three dimensions of corporate social responsibility. The aim is to show how this typology development could provide a useful approach to integrating the diverse strands of sustainability in operations, using industrial ecology and carbon neutrality as examples. It does this by providing a focused subset of environmental concerns for an industrial ecology approach, and some research propositions for the issue of carbon neutrality.
\end{abstract}

Keywords: operations management, sustainability, environment, typology

\section{Introduction}

Sustainability and sustainable development are terms that have become prominent in everyday life over recent years, particularly associated with the debates around global warming and corporate social responsibility. These themes have gained increased profile in such recent films as An Inconvenient Truth (Bender \& David, 2006) and The Corporation (Achbar \& Simpson, 2003). This paper aims to make an initial (and modest) attempt to integrate these themes as they relate to operations management, and to generate discussion for its future development. The typology also aims to help managers adopt an integrated approach to sustainable operations. 
Operations management (OM) has been defined, in a recent popular textbook (Chase, Jacobs, \& Aquilano, 2006) as "the design, operation, and improvement of the systems that create and deliver the firm's primary products and services" (2006: 9). Similarly, an older text (Constable \& New, 1976) describes OM as being "concerned with the management of the physical resources required for production, whether the product be a manufactured item or a service" (1976:1). The efficient management of these resources and systems is important because the number of people employed in this area is likely to exceed that in other functional areas and, as a consequence, a large proportion of total spending is consumed in the operations area. Also in most manufacturing firms, "about 80 percent of total capital investment will be in the operations area" (1976:1). The current concern for the environment and increased awareness of global warming means the sustainable management of these resources and systems has become very important. Hawken et al. (1999) highlight the manifest resource inefficiency of many of the current products and production processes and claim that about one percent of all material that originates at the top of the supply chain serving the United States remains in use six months after sale of the products containing it (Hawken, Lovins, \& Lovins, 1999). This paper makes an attempt to integrate much recent work on sustainability in the OM area into a typology that might be useful for researchers and practitioners. This paper considers the issues of sustainability and sustainable development in the management literature, and then considers briefly how business has adopted these ideas through the notions of corporate social responsibility (the triple bottom line) and corporate sustainability. The paper then extends this debate to the operations management field and how the focus has changed from environmental operations management to, more recently, sustainable operations and sustainable supply chain. The paper then attempts to develop a typology based on the elements of life cycle analysis and the triple bottom line.

\section{Sustainability and sustainable development}

The term sustainable development has a long history in the natural sciences and field of environmentalism. For a discussion of this history, see for example (Dryzek, 1997; Jamieson, 2001). This term entered onto the political and business agenda in the 1980s with the release of Our Common Future (WCED, 1987), also known as the Brundtland report. This report defines sustainable development (SD) as "development that meets the needs of the present without compromising the 
ability of future generations to meet their own needs" (1987: 8). Tregidga and Milne note that it has a 'palatable or optimistic quality' (2006: 221), compared to the 'doom and gloom' stance of much of the prior literature (e.g. Ehrlich, 1968; Hardin, 1968; Meadows, Meadows, Randers, \& Behrens, 1972) and it was this that made the concept appealing to a wider audience including business. Business activity dominates every stage of the value creation and production chain and the scale of the resulting impacts on the natural environment can be immense. These activities consume vast amounts of resources with consequent impact on greenhouse gas emissions and human-induced climate change. Consequently, businesses can also serve as powerful instruments of change in achieving a sustainable, or at least a less unsustainable future state (Hawken, 1993; Shrivastava, 1995; Tang \& Yeoh, 2007; Tregidga et al., 2006; Welford, 1997).

The open definition proposed by the WCED report has led many researchers to develop alternative formulations that are aimed at being easier to operationalize. Gladwin et al. (1995) listed some of the more detailed and/or leading definitions proposed by that time (Gladwin, Kennelly, \& Krause, 1995). These authors analysed the various definitions proposed and they suggest there are five components that are common to these definitions. They are inclusiveness which implies 'an expansive view in terms of space time and component parts of the manifest world' (1995: 878); connectivity which recognizes interconnections and interdependencies in the world's problems; equity which is to do with a fair distribution of resources within and between generations; and prudence which implies the need to ensure life supporting ecosystems and interrelated socioeconomic systems are resilient and 'for keeping the scale and impact of human activities within the regenerative and carrying capacities.' (1995: 879)

Sustainable development, however loosely defined, has been popularised by the Brundtland report and succeeding events like the Earth Summits in Rio de Janeiro in 1995 and in Johannesburg in 2005. It is recognized as the societal guiding model, which addresses a broad range of quality of life issues in the long term (Steurer, Langer, Konrad, \& Martinuzzi, 2005). At the corporate level, the application of SD to business "is often referred to as Corporate Sustainability" (2005: 274).

"For the business enterprise, SD means adopting business strategies and activities that meet the needs of the enterprise and its stakeholders today while protecting, 
sustaining, and enhancing the human and natural resources that will be needed in the future" (Dyllick \& Hocketts, 2002: 131).

The acceptance of a social role for business has led to the development of the field of stakeholder management (Freeman, 1984; Mitchell, Agle, \& Wood, 1997) and the allied field of corporate social responsibility (CSR) (Waddock, 2004) with its three pillars of economic, environmental and social dimensions, also known as the triple bottom line (Elkington, 1999). Steurer et al. note that SD, CS and CSR are closely connected yet 'on different levels of specification with different conceptual nuances. In this sense, SD can be regarded as the normative societal concept behind the other two, CS as the corporate concept and CSR as the management approach.' (2005: 275).

\subsection{Sustainability in operations}

Research that focuses on sustainability in operations has been attracting much interest over recent years. As is to be expected in this broad area, there are a number of approaches that researchers have taken, ranging from applying CSR to supply chains to examining the implications of sustainability for different parts of the supply chain or value chain. Work in the former area tends to be more focused on the societal and human aspects of business behaviour, often at the industry level. There has been research into establishing the main elements of the supply chain CSR that apply across industries, for example (Carter, 2004; Carter \& Jennings, 2002a, 2002b, 2004), and as there will always be fairly unique supply chains within different industries, these will have their own supply chain CSR issues. Mamic (2005) studied the implementation of the Codes of Conduct that a number of multi-national enterprises, particularly in the sports footwear, and apparel industries, introduced in order to influence or provide guidelines for their suppliers in a range of areas such as child labour, forced labour, wages and benefits, working hours, disciplinary addresses, safety, and environmental practices (Mamic, 2005). Among the companies she studied, she found varying degrees of success in implementing the codes of conduct and notes that the notion of CSR across a global supply chain continues to evolve rapidly. In a study in the food industry (Maloni \& Brown, 2006), the authors discuss the unique supply chain that exists which includes animal welfare, biotechnology, fair trade, and labour and human rights issues as well as health and safety, and environmental practices, and propose a framework for operations managers and researchers. 
Research that integrates the environmental and resource impacts of products and services has been the other area of sustainable OM research and is the focus of the remainder of this paper. Research in these areas has changed quite substantially in its emphasis over the last decade, though earlier OM innovations that concerned resource usage, such as TQM, JIT, and lean manufacturing have a longer history. The initial emphasis was more likely to be on environmental practices and organizational 'greening' (Klassen, 2001; Winn \& Angell, 2000). Kolk and Mauser (2002) discuss the evolution of environmental management models and note how they have developed from stage or phase models to those dealing with the organizational and strategic complexities of the area, and to those incorporating environmental performance evaluations systems (Kolk \& Mauser, 2002). While more recently in OM there has been increased interest in remanufacturing and closed-loop supply chains (see for example (Flapper, Nunen, \& Wassenhove, 2005; Guide J r., Jayaraman, Srivastava, \& Benton, 2000; Majumder \& Groneveldt, 2001). These changes are noted in a recent article (Kleindorfer, Singhal, \& Van Wassenhove, 2005) that discusses the research on sustainable OM that has appeared in three special issues of the POM journal. Linton et al. (2007) note that research on supply chains has focused on maximising value across the chain, even if parts were required to operate sub-optimally. The supply chain runs from the processing of raw materials to delivery to the end customer but from a sustainability perspective it is necessary to widen this view of the supply chain to include design activities, dealing with by-products of manufacture or use, as well as the end-of-life processes of recovery or disposal (Linton, Klassen, \& Jayaraman, 2007). This widening creates a new set of opportunities for operational improvement that may require short-term asset investments (Corbett \& Klassen, 2006) but it also requires investment in the use of such tools as life cycle analysis (LCA) (Hertwich, Hammitt, \& Pease, 2000) to improve closed-loop supply chains (e.g. (Sarkis, 1995; Sroufe, 2004) or to broaden companies' sustainability efforts (Mihelcic et al., 2003). In an introduction to a special issue on sustainable supply chains in Journal of Operations Management, Linton et al (2007) review some of the operations management literature related to each of the LCA stages, and note that the papers in the special issue cross disciplinary boundaries as the concepts of sustainability and the triple bottom line bring in social and regulatory (policy) dimensions as well as operations issues. Matos and Hall reinforce this by pointing out that techniques such as LCA, while 'theoretically elegant' (Matos \& Hall, 2007): 1083) are not easy to apply in practice because of interacting variables and fluid 
boundaries of responsibility. They chose to use the concept of fitness landscapes (Kauffmann, 1993; Levinthal \& Warglein, 1999) to study the increasing complexity associated with the interactions of LCA with the stakeholders in their case studies. In yet another journal special issue in this field, the International Journal of Production Research (vol 45, issue18-19) recently published a suite of papers on "Sustainable Design and Manufacture". The papers covered a raft of concepts and practices that demonstrated how a responsible approach to design and manufacture of today's products can mean reduced consumption of non-renewable resources throughout a product's life-cycle. Topics included 'design for environment, environmentally conscious/benign manufacture, waste minimization, dematerialization and product service systems, energy conservation and management, green/sustainable supply chain management, product end-of-life management and reverse logistics' (Rahimifard \& Clegg, 2007).

We have discussed the importance of efficient resource use in OM and how this links to sustainability/sustainable development. We have discussed the meaning of sustainability and its links to the natural environment and social issues through the business ethicists' concept of corporate social responsibility or triple bottom line. We then reviewed some of the approaches in the literature to applying these concepts to operations management, how the field has changed from a study of plant-level environmental practices to the more 'systemic issues that exist at the intersection of sustainability, environmental management and supply chains' (Linton et al 2007:1075), and the increased need to consider the 'cradle-to-grave' approach of life-cycle analysis in products and services (Graedel, 1997; Mihelcic et al., 2003). This paper now continues by considering the use of typologies in operations management research, and explores the development of a typology - or classification - for sustainable OM.

\section{Typologies}

As noted by Doty and Glick (1994: 235), typologies "are a unique form of theory based on a set of ideal types". Typologies have proven very popular in management research with many well-known examples, such as those of Porter (1980, 1985), Miles and Snow (1978), and Mintzberg (1979, 1983). They are also popular in OM research with well-known examples being those proposing different types of service firms (Chase, 1978, 1981; Chase \& Tansik, 1983). This paper does not aim to develop a set of ideal types but to suggest how typologies might be developed to 
assist educators, researchers and managers interested in sustainable operations management concepts, models and applications. As such this paper follows Adam Jr. (1983:366), who, in discussing OM, notes 'a limitation of any typology for production/operations is that the typology does not provide an integrative theory for the discipline'. So the purpose of this paper is modest in seeking to show how a typology could assist in bringing together the diverse strands of the sustainability/sustainable development literature as it applies to the OM field or function, so that propositions may be developed and then tested, thus leading eventually to theory development for the field (Adam J r., 1983).

\subsection{A typology for sustainable operations management}

The starting point for the proposed typology derives from the discussion above where the importance of the "cradle-to-grave" approach of LCA was noted and the increased pressure on businesses from their stakeholders for corporate social responsibility. In this section of the paper, the author develops the proposed typology in stages, moving from the basic dimensions and sequentially adding more detail. In this way it is hoped that the development will be clearly understood, Thus the initial categories for the typology as shown in Figure 1 are taken from the literature discussed above and shows the intersection of corporate social responsibility and the life cycle of a product.

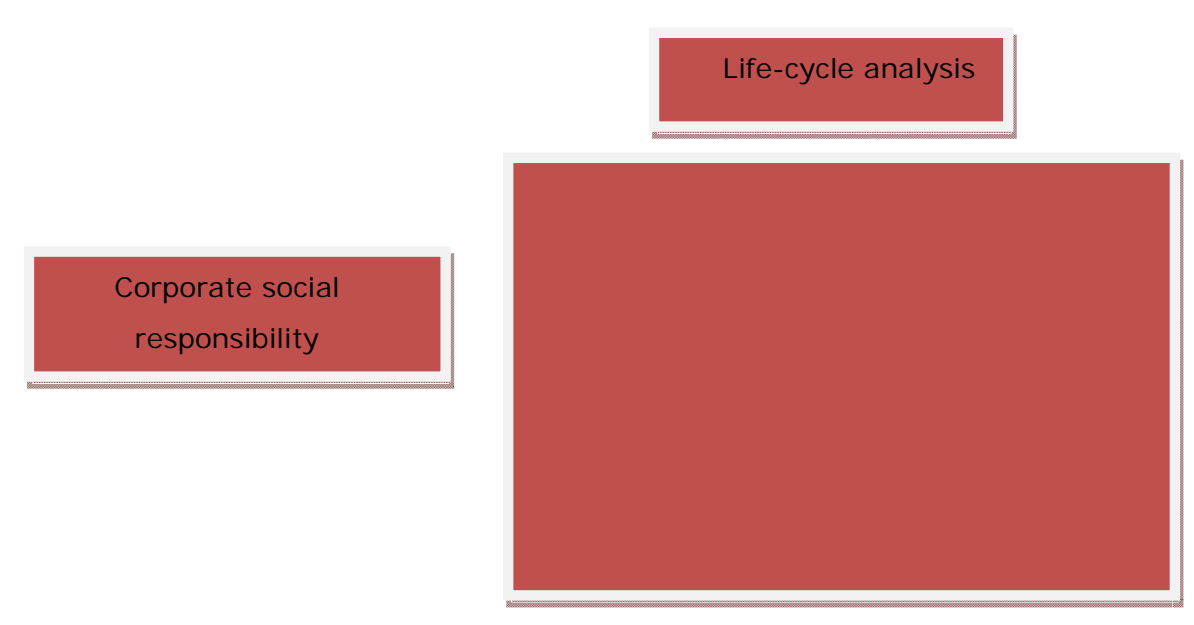

Figure 1. "Life-cycle analysis and corporate social responsibility". Source: author

The next step is to make an initial expansion of the two axes of the typology. The LCA covers the efficient use of resources at each stage of the process for the 
product or service (based on Allenby, 1995). The life cycle of a product is expanded into five generic stages from design to manufacture, distribution, use and end-oflife treatments. The CSR dimension on the vertical axis is expanded into the three dimensions proposed by Elkington (1998), economic, environmental and social sustainability, to which the business's processes are expected to respond or to take into account. If the initial categories from Figure 1 are now expanded to component dimensions, we have the revised arrangement shown in Figure 2 (for a product).

\begin{tabular}{|c|c|c|c|c|c|}
\cline { 2 - 6 } \multicolumn{1}{c|}{} & $\begin{array}{c}\text { Design and } \\
\text { preproduction }\end{array}$ & $\begin{array}{c}\text { Product } \\
\text { manufacture }\end{array}$ & $\begin{array}{c}\text { Product } \\
\text { packaging and } \\
\text { distribution }\end{array}$ & Product use & $\begin{array}{c}\text { End-of-life } \\
\text { recycling, } \\
\text { remanufacturing, } \\
\text { disposal }\end{array}$ \\
\hline $\begin{array}{c}\text { Economic } \\
\text { sustainability }\end{array}$ & & & & & \\
\hline $\begin{array}{c}\text { Environmental } \\
\text { sustainability }\end{array}$ & & & & & \\
\hline $\begin{array}{c}\text { Social } \\
\text { sustainability }\end{array}$ & & & & & \\
\hline
\end{tabular}

Figure 2. "Life cycle stages and CSR dimensions". Source: author

The three pillars of CSR are rather broad headings and these need to be split into their components to give guidance to educators, researchers, and managers. The economic sustainability pillar refers to the intention of the firm to carry out its business activities in a way that enables it to continue for an indefinite time, and so is concerned with long-term financial performance and competitiveness and cost efficiency. Environmental sustainability pillar relates to the company's maintenance of its natural capital to whatever degree possible and so is concerned with the impact and risk of company's processes on the environment and issues around use of resources and emissions. Social sustainability refers to how the company contributes to the social well-being of the society and neighbourhood in which it operates, and the individuals who work for it (Steurer et al., 2005). This leads to the next expansion, or more detailed level, of the typology as shown in Figure 3. The use of levels of analysis is consistent with earlier proposed typologies, e.g. Mintzberg (1978) studied the structure of organizations from the foundation level (how organizations actually functioned), upward to the synthesis level where he showed structural configurations. The typology has many uses in theory-building and in linking with existing work in subsets of the dimensions. These are discussed in the next section. Managers in leading companies are now realising that taking 
action across the intersections of the matrix makes economic as well as moral sense. The CEO of Walmart was quoted in Fortune (Gunther, 2006) as follows:

“There can't be anything good putting all those chemicals in the air. There can't be anything good about the smog you see in cities. There can't be anything good about putting chemicals in those rivers in Third World countries so that somebody so someone can buy an item for less money in the developed world. Those things are inherently wrong, whether you are an environmentalist or not."

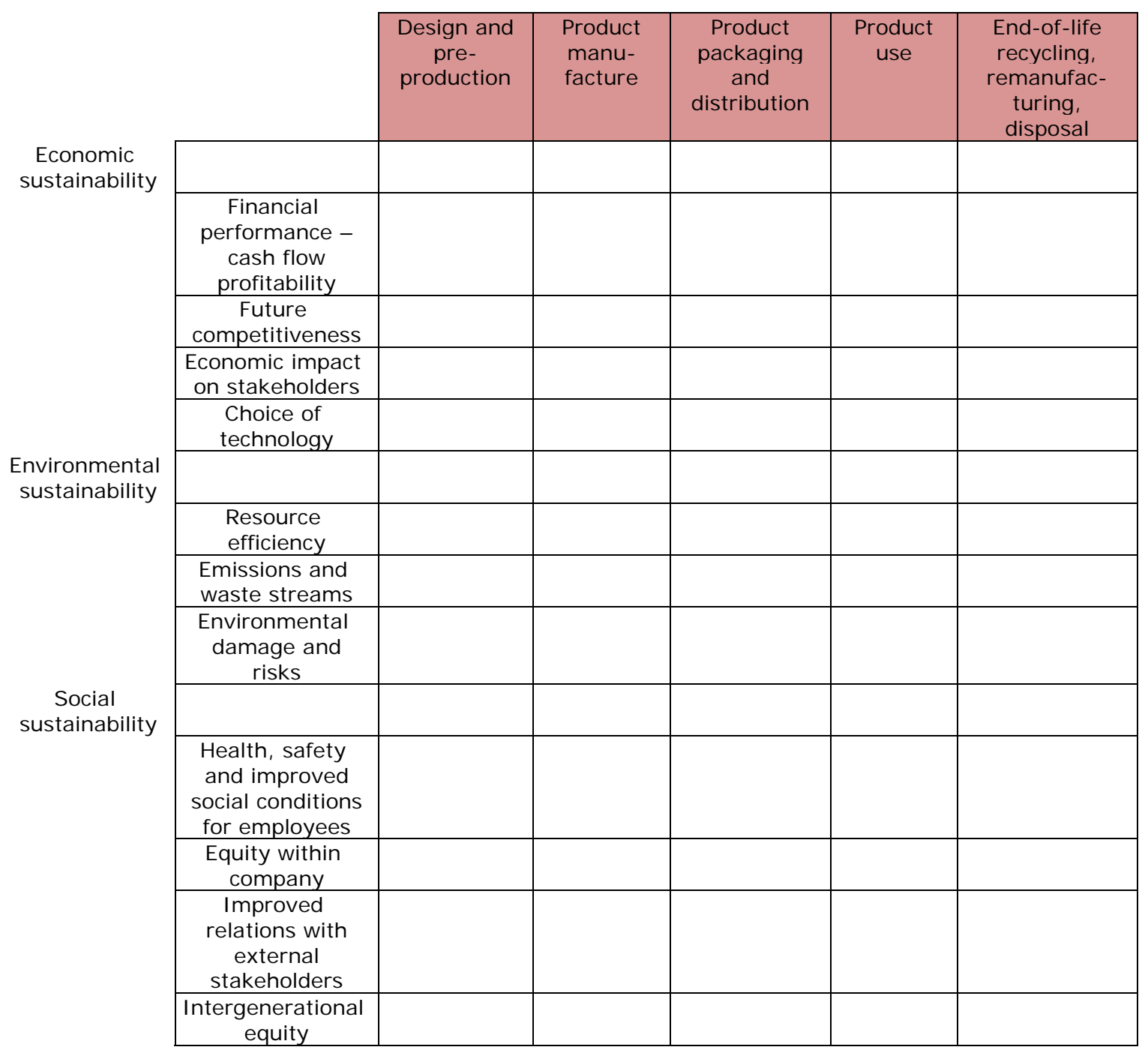

Figure 3. "A typology for sustainable operations management (manufactured product example)". Integrating life-cycle stages and CSR responses. Source: author 


\subsection{Uses of the proposed typology}

As noted earlier, sustainability issues tend to be multidisciplinary in nature. Industrial ecology is the study of coupled economic and environmental systems and has been used to assist understanding and implementation of sustainable development in firms (Allenby, 1995). A subset of the proposed typology can be taken that shows where industrial ecology studies would fit. Figure 4 takes the life cycle stages and combines them with one of the environmental management dimensions, and produces an adaptation of Allenby's matrix for helping 'a manager create environmentally responsible products and processes' (1995:46). Allenby describes how trained assessors use detailed checklists and other evaluation techniques that are common in the engineering field to develop a semi-qualitative overall rating for each cell, and that, with experience and more data, these assessors can 'begin to implement quantitative techniques, making checklists more rigorous.' (1995: 46).

\begin{tabular}{|c|c|c|c|c|c|}
\hline \multicolumn{2}{|c|}{ Life cycle stage. } \\
\hline $\begin{array}{c}\text { Environmental } \\
\text { concern }\end{array}$ & $\begin{array}{c}\text { Design and } \\
\text { preproduction }\end{array}$ & $\begin{array}{c}\text { Product } \\
\text { manufacture }\end{array}$ & $\begin{array}{c}\text { Product } \\
\text { packaging } \\
\text { and } \\
\text { distribution }\end{array}$ & $\begin{array}{c}\text { Product } \\
\text { use }\end{array}$ & $\begin{array}{c}\text { End-of-life } \\
\text { recycling, } \\
\text { remanufacturing, } \\
\text { disposal }\end{array}$ \\
\hline $\begin{array}{c}\text { Resource } \\
\text { efficiency: } \\
\text { Material choice }\end{array}$ & & & & \\
\hline $\begin{array}{c}\text { Resource } \\
\text { efficiency: } \\
\text { Energy use } \\
\text { Emissions and } \\
\text { waste streams: } \\
\text { Solid residues } \\
\text { Liquid residues } \\
\text { Gaseous } \\
\text { residues }\end{array}$ & & & & & \\
\hline
\end{tabular}

Figure 4. "Industrial ecology subset of typology". Source: adapted from Allenby (1995)

\subsection{Carbon neutrality as an example of sustainability and using the typology}

As mentioned in the opening paragraph, the issue of global warming or climate change has increasingly become the focus of attention of individuals, organizations and governments over the last few years. This is due to the recognition that most of the increase in greenhouse gas (GHG) emissions that are responsible for global warming are due to human activity (IPCC, 2007). So climate change has moved from an environmental problem to a societal issue and now to a business issue as 
governments work toward putting a price on carbon content of emissions, institute 'cap and trade' regimes, and sign up to international agreements like the Kyoto Protocol. A carbon neutral company is one that reduces its own emissions as far as possible, and offsets, or buys carbon credits for, the remaining emissions. As the Carbon Trust notes this term is "commonly accepted terminology for something having net zero emissions (for example, an organization or product). As the organization or product will typically have caused some greenhouse gas emissions, it is usually necessary to use carbon offsets to achieve neutrality. Carbon offsets are emissions reductions that have been made elsewhere and which are then sold to the entity that seeks to reduce its impact. In order to become carbon neutral it is important to have a very accurate calculation of the amount of emissions which need to be offset - requiring calculation of a carbon footprint.' (TheCarbonTrust, 2007).

\begin{tabular}{|c|c|c|}
\hline $\begin{array}{c}\text { Economic } \\
\text { sustainability }\end{array}$ & & Service design and delivery \\
\hline & $\begin{array}{l}\text { Financial performance - cash } \\
\text { flow, profitability } \\
\text { Future competitiveness }\end{array}$ & $\begin{array}{l}\text { Cost reductions through energy savings } \\
\text { Increased competitive advantage from } \\
\text { positive effects of being carbon neutral }\end{array}$ \\
\hline & $\begin{array}{l}\text { Economic impact on } \\
\text { stakeholders } \\
\text { Choice of technology }\end{array}$ & $\begin{array}{l}\text { Dividends, capital gains on stocks, taxes paid } \\
\text { to government } \\
\text { Yield management; dematerialization of } \\
\text { tangibles in service bundle; energy efficiency } \\
\text { improvements in lighting, air conditioning } \\
\text { etc.; smart buildings }\end{array}$ \\
\hline \multicolumn{3}{|l|}{$\begin{array}{l}\text { Environmental } \\
\text { sustainability }\end{array}$} \\
\hline & Resource efficiency & $\begin{array}{c}\text { Process design focused on reducing energy } \\
\text { and natural resource consumption in } \\
\text { operations; production planning and control } \\
\text { focused on reducing waste and optimizing } \\
\text { materials usage }\end{array}$ \\
\hline & Emissions and waste streams & $\begin{array}{c}\text { Buy or generate renewable energy (solar, } \\
\text { wind, hydro); waste reduction and recycling }\end{array}$ \\
\hline & $\begin{array}{c}\text { Environmental damage and } \\
\text { risks }\end{array}$ & $\begin{array}{l}\text { Preference for green products in purchasing; } \\
\text { environmental criteria in supplier selection }\end{array}$ \\
\hline \multicolumn{3}{|l|}{$\begin{array}{c}\text { Social } \\
\text { sustainability }\end{array}$} \\
\hline & $\begin{array}{l}\text { Health, safety and improved } \\
\text { social conditions for employees }\end{array}$ & $\begin{array}{l}\text { Improved ergonomics in workplaces, changes } \\
\text { in working practices that reduce travel and } \\
\text { energy use, teleworking or telecommuting } \\
\text { possibilities }\end{array}$ \\
\hline & Equity within company & $\begin{array}{l}\text { Changes in working practices to involve all } \\
\text { staff in carbon neutral improvement activities }\end{array}$ \\
\hline & $\begin{array}{l}\text { Improved relations with } \\
\text { external stakeholders }\end{array}$ & $\begin{array}{l}\text { Improved financial performance from brand } \\
\text { enhancement leads to more secure jobs, } \\
\text { regular voluntary information on progress } \\
\text { issued }\end{array}$ \\
\hline & Intergenerational equity & Buy carbon offsets, plant trees \\
\hline
\end{tabular}

Figure 5: Towards carbon neutrality - subset of typology. Source: author 
Lovins (2008) notes that for companies taking action to reduce their GHG emissions they are beginning to realise that this is a "no regrets" strategy. "if climate change turns out to be real, they will be in a leadership position by dealing responsibly with it. Even if the scientists are wrong, and there is no threat to the climate, these are actions that a well-managed business would want to take anyway because doing so is profitable"(2008:23).

At the firm level, it is possible to take a vertical slice of the typology and suggest some of the OM principles that might be applied in order for a firm to become carbon neutral, adapted from (Gladwin et al., 1995; Gonzalez-Benito \& GonzalezBenito, 2006; Kolk \& Pinkse, 2005). A service firm example is used in Figure 5.

Alternatively, this example could be stated more formally and a proposition such as the following could be developed.

Proposition 1: Overall organization performance toward carbon neutrality is higher if all three dimensions of economic, environmental and social sustainability are emphasized.

This could possibly be tested using secondary data such as the increasing number of case studies becoming available in this area, for example see (CarbonSense, 2006; The Carbon Trust, 2007). Suitable measures would range from traditional financial measures (e.g. ROI, profitability, cash flow, changes in working capital), to environmental measures related to emissions reductions and reductions in energymatter throughput per unit of output (Gladwin et al., 1995), and to social measures such as reduced travel and energy use by employees.

Earlier in this paper, we discussed the evolution of sustainable OM research from a focus on environmental practices at the plant level to a focus on sustainable supply chains. The latter encompassed all the stages of a product life-cycle. Supply chain management has been used successfully for many years to improve their financial performance. Successful companies have expanded their field of vision to look at the processes and operations of the companies that they buy from and companies that they sell to. This has allowed them to make better, more informed decisions about how to run their own operations. Many benefits have been seen such as improved productivity, increased efficiency, reduced waste, lower capital requirements and enhanced product development (The Carbon Trust, 2006). Sustainable supply chains will impact on all intersections in the proposed typology, 
and continuing the example of carbon neutrality as part of sustainable development, a firm's position in the supply chain will affect the amount of 'pressure' it is under to become carbon neutral (Gonzalez-Benito et al., 2006; Kolk et al., 2005). This could be developed as proposition 2. Proposition 3 is developed to test the approach taken by firms in the supply chain to achieve carbon neutrality. The minimization of one's own emissions, also known as internal abatement (The Carbon Trust, 2006) should be the starting point for any carbon neutral strategy as these can be no cost or low cost measures.

Proposition 2: for manufacturers of finished products and for service operations, overall organization performance toward carbon neutrality is more likely than for firms further back in the supply chain.

Proposition 3: independent of position in the supply chain/value chain, overall organization performance toward carbon neutrality is higher if firms seek absolute reductions in GHG before purchasing offsets.

If we recognise that all the emissions across the economy are generated to meet the needs of the end consumer. For example, bauxite is not made into aluminum because aluminum ingots themselves are useful but because they, in turn, can be made into components for the automobiles we all drive, and the windows for the buildings we all live in. To understand fully the carbon emissions associated with, say, the aluminum content of our automobiles, we need to consider not only the energy used to run them but also the energy used to make and deliver all the aluminium parts, and the energy to dismantle, dispose and recycle them afterwards too. Could a supply chain approach be used just as successfully in the drive to cut carbon emissions across the economy and for whole industries to work towards sustainability through becoming carbon neutral? As an example of this kind of thinking, the World Aluminium Council has recently claimed its members can achieve carbon neutrality - despite being major users of primary energy - thanks to carbon dioxide reduction achieved making cars from aluminium not steel, which reduces their weight and thus increases fuel efficiency (IAI, 2007).

Proposition 4: An industry supply chain could achieve carbon neutrality if the price received per $\mathrm{kg}$ of material in the final product exceeds the cost of transformation from raw material by sufficient margin to purchase enough offsets for all emission for all stages of the product life cycle. 
If we continue the aluminium example, measures for this proposition would be the price per $\mathrm{kg}$ of aluminum that end customers are willing to pay for carbon neutral aluminium in their automobiles, the actual cost of getting the aluminum to that stage through all processing steps, and associated emissions valued at the international carbon price.

\section{Conclusions}

This paper has attempted to develop a typology for sustainable operations management. It has some of the characteristics of acceptable typologies: there are a few distinct categories, group-by-group comparisons are possible, and the typology could lead to causal relationships and synthesis (Adam Jr., 1983; Heydebrand, 1973). It uses the stages of life cycle and the three pillars of corporate social responsibility as the basic dimensions for the typology. The paper shows that by taking subsets of the typology it can be linked with the industrial ecology field. The paper takes the issue of carbon neutrality as an example of how the typology could be used and shows how testable propositions could be developed.

\subsection{Managerial implications}

The proposed typology would be useful for managers who are engaging in improvement projects around sustainability issues such as GHG reduction and who wish or need to extend their organisation's efforts more broadly in terms of CSR. They could use the cells of the typology as a kind of checksheet of where they have focused their attention and what areas still need working on.

\subsection{Theoretical implications and future research}

Future research could contribute to refining the meaning of many of the concepts used in this field, such as sustainability, and to the issues of measurement and who can claim emission reduction credits on the boundaries of a firm's operations.

Much research in the area of sustainability and sustainable development has, as mentioned in the earlier parts of the paper, been more confined to one area of interest e.g. just operations management or supply chains, or just to the social development aspects of sustainable practices. This typology is more broadly multidisciplinary and offers researchers opportunities to develop approaches incorporating all areas of the typology matrix to examine what organisations are 
doing or need to do to become truly sustainable. In this way use of the typology would expand and modify the narrower approaches currently in use.

\subsection{Limitations}

The typology does not propose ideal types (Doty \& Glick, 1994), as these would be an area for future research. Typological research usually aims to develop ideal types and give names to clusters of organisations that emerge in this type of research.

\section{References}

Achbar, M. \& Simpson, B. (2003). The Corporation. USA: Big Picture Media Corporation.

Adam Jr., E.E. (1983). Towards a typology of production and operations management systems. Academy of Management Review, 8(3), 365-375.

Allenby, B. R. (1995). Implementing industrial ecology: The AT\&T matrix system. Interfaces, 30(3), 42-54.

Bender, L., \& David, L. (2006). An Inconvenient Truth. USA: Paramount Classics.

CarbonSense (2008). What would a genuinely carbon neutral BT look like; Retrieved J anuary 2008 from www. carbonsense.org.

Carter, C. R., \& Jennings, M. M. (2002a). Social responsibility and supply chain relationships. Transportation Research, Part E, 38E(One), 37-52.

Carter, C. R., \& Jennings, M. M. (2002b). Logistics social responsibility: an integrative framework. J ournal of business logistics, 23(One), 145-180.

Carter, C. R. (2004). Purchasing and social responsibility: A replication and extension. Journal of the supply chain management, 36(One), 45-56.

Carter, C. R., \& Jennings, M. M. (2004). The role of purchasing and corporate social responsibility: a structural equation analysis. Journal of business Logistics, 25(1), 145-186. 
Chase, R. B. (1978). Where does the customer fit in a service operation? Harvard Business Review, 56(6), 137-142.

Chase, R. B. (1981). The customer contact approach to services. Operations Research, 29(4), 698-705.

Chase, R. B., \& Tansik, D. A. (1983). The customer contact model for organizational design. Management Science, 29(9), 1037-1050.

Chase, R. B., Jacobs, F. R., \& Aquilano, N. J. (2006). Operations management for competitive advantage (11th ed.). New York: McGraw-Hill Irwin.

Constable, C. J., \& New, C. C. (1976). Operations management: A systems approach through text and cases. Chichester: Wiley.

Corbett, C. J., \& Klassen, R. D. (2006). Extending the horizons: Environmental excellence as key to improving operations. Manufacturing and Service Operations Management, 8(1), 5-22.

Doty, D. H., \& Glick, W. H. (1994). Typologies as a unique form of theory building: Toward improved understanding and modeling. Academy of Management Review, 18(2), 230-251.

Dryzek, J. (1997). The politics of the earth: Environmental discourses. Oxford: Oxford University Press.

Dyllick, T., \& Hocketts, K. (2002). Beyond the case for corporate sustainability. Business Strategy and the Environment, 11, 130-141.

Ehrlich, P. (1968). The population bomb. New York: Ballantine.

Elkington, J. (1999). Cannibals with forks: the triple bottom line of 21st century business. Oxford: Capstone.

Flapper, S. D., Nunen, J. A. E. E. v., \& Wassenhove, L. N. v. (2005). Managing closed-loop supply chains. Berlin: Springer.

Freeman, R. E. (1984). Strategic management: A stakeholder approach. Boston: Pitman. 
Gladwin, T. N., Kennelly, J. J., \& Krause, T.S. (1995). Shifting paradigms for sustainable development: Implications for management theory and research. Academy of Management Review, 20(4), 874-907.

Gonzalez-Benito, J., \& Gonzalez-Benito, O. (2006). A review of determinant factors of environmental proactivity. Business Strategy and the Environment, 15, 87-102.

Graedel, T. E. (1997). Life cycle assessment in the service industries. Journal of Industrial Ecology, 1(4), 57-70.

Guide J r., V. D. R., Jayaraman, V., Srivastava, R., \& Benton, W. C. (2000). Supplychain management for recoverable manufacturing practices. Interfaces, 30(3), 125-142.

Hardin, G. (1968). The tragedy of the commons. Science, 162, 1243-1248.

Gunther, M. (2006). “The green machine”. Fortune Magazine, Retrieved 2006 from http://money.cnn.com/magazines/fortune/fortunearchive/2006/08/07/8382593/ index.htm

Hawken, P. (1993). The ecology of commerce; A declaration of sustainability. New York: HarperCollins.

Hawken, P., Lovins, A. H., \& Lovins, L. H. (1999). Natural capitalism. Boston: Little Brown \& Company.

Hertwich, E., Hammitt, J., \& Pease, W. (2000). A theoretical foundation for lifecycle assessment. Journal of Industrial Ecology, 4(1), 13-28.

Heydebrand, W. V. (1973). Comparative organizations: The results of empirical research. Englewood Cliffs NJ: Prentice-Hall.

IAI. (2008) Improving sustainability in the transport sector through weight reduction and the application of aluminium; Retrieved January 2008 from http://www.world-aluminium.org/cache/fl0000124.pdf.

IPCC. (2007). Climate Change 2007 - Fourth Assessment Report; Retrieved January 2008 from http://www.ipcc.ch/ipccreports/ar4-syr.htm. 
Jamieson, A. (2001). The making of green knowledge: Environmental politics and cultural transformation. Cambridge: Cambridge University Press.

Kauffmann, S. (1993). The origins of order. Oxford: Oxford University Press.

Klassen, R. D. (2001). Plant-level environmental orienation: The influence of management views and plant characteristics. Production and Operations Management, 10(3), 257-275.

Kleindorfer, P. R., Singhal, K., \& Van Wassenhove, L. N. (2005). Sustainable operations management. Production and Operations Management, 14(4), 482492.

Kolk, A. \& Mauser, A. (2002). The evolution of environmental management: From stage models to performance evaluation. Business Strategy and the Environment, $11,14-31$.

Kolk, A. \& Pinkse, J. (2005). Business responses to climate change: Identifying emergent strategies. California Management Review, 47(3), 6-20.

Levinthal, D. A. \& Warglein, M. (1999). Landscape design: designing for local action in complex worlds. Organization Science, 10(3), 342-357.

Linton, J. D., Klassen, R. D., \& Jayaraman, V. (2007). Sustainable supply chains: An introduction. Journal of Operations Management, 25, 1075-1082.

Lovins, L. H. (2008). The Business case for climate protection, in M. V. Russo (Ed) Environmental Management: Reading and Cases, 15-39, Los Angeles, Sage

Majumder, P. M. \& Groneveldt, H. G. (2001). Competition in remanufacturing. Production and Operations Management, 10(2), 125-141.

Maloni, M. J., \& Brown, M. E. (2006). Corporate social responsibility in the supply chain: an application in the food industry. Journal of business ethics, 68, 35-52.

Mamic, I. (2005). Managing global supply chain: the sports footwear, apparel and retail sectors. J ournal of Business Ethics, 59, 81-100. 
Matos S., \& Hall, J. (2007). Integrating sustainable development in the supply chain: The case of life cycle assessment in oil and gas and agricultural biotechnology. J ournal of Operations Management, 25, 1083-1102.

Meadow, D. H., Meadows, D. I., Randers, J., \& Behrens, W. H. (1972). The limits to growth. New York: Universe.

Mihelcic, J. R., Crittenden, J. C., Small, M. J., Shonnard, D. R., Hokanson, D. R., Zhang, Q., Chen, H., Sorby, S. A., \& James, v. U. (2003). Sustainability science and engineering: The emergence of a new metadiscipline. Environmental Science and Technology, 37, 5314-5324.

Miles, R. E., \& Snow, C. C. (1978). Organization strategy, structure, and process. New York: McGraw-Hill.

Mintzberg, H. T. (1979). The structuring of organizations. Englewood Cliffs NJ: Prentice-Hall.

Mintzberg, H. T. (1983). Structure in fives: Designing effective organizations. Englewood Cliffs NJ: Prentice-Hall.

Mitchell, R. K., Agle, B. R., \& Wood, D. J. (1997). Toward a theory of stakeholder identification and salience: Defining the principle of who and what really counts. Academy of Management Review, 22(4), 853-886.

Porter, M. E. (1980). Competitive strategy: Techniques for analyzing industries and competitors. New York: Free Press.

Porter, M. E. (1985). Competitive advantage; Creating and sustaining superior performance. New York: Free Press.

Rahimifard, S., \& Clegg, A. J. (2007). Aspects of sustainable design and manufacture. International Journal of Production Research, 45(18-19), 40134019.

Sarkis J. (1995). Supply chain management and environmentally conscious design and manufacturing. International Journal of Environmentally Conscious Design and Manufacturing, 4(2), 43-52. 
Shrivastava, P. (1995. The role of corporations in achieving ecological sustainability. Academy of Management Review, 20(4), 936-960.

Sroufe, R. (2004. Effects of environmental management systems on environmental management practices and performance. Production and Operations Management, 12(3), 416-431.

Steurer, R., Langer, M. E., Konrad, A., \& Martinuzzi, A. (2005. Corporations, stakeholders and sustainable development I: A theoretical exploration of business-society relations. Journal of Business Ethics, 61, 263-281.

Tang, K. \& Yeoh, R. (2007. Cut carbon, grow profits: Business strategies for managing climate change and sustainability. London: Middlesex University Press.

The Carbon Trust. (2008) Carbon footprints in the supply chain: The next step for business; Retrieved January 2008 from http://www. carbontrust. co. uk/publications/publicationdetail? productid=CTC616.

The Carbon Trust. (2008) Glossary of terms; f Retrieved January 2008 from http://www.carbontrust.co.uk/solutions/CarbonFootprinting/carbon_footprinting glossary.htm

Tregidga, H., \& Milne, M. J. (2006). From sustainable management to sustainable development: A longitudinal analysis of a leading New Zealand environmental reporter. Business Strategy and the Environment, 15, 219-241.

Waddock, S. (2004). Parallel universes: Companies, academics, and the progress of corporate citizenship. Business and Society Review, 109(1), 5-42.

WCED. (1987). Our common future. Oxford: Oxford University Press.

Welford, R. (1997). Hijacking environmentalism: Corporate response to sustainable development. London: Earthscan.

Winn, M. I., \& Angell, L. C. (2000). Toward a process model of corporate greening. Organization Science, 21(6), 1119-1147. 


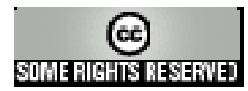

Article's contents are provided on a Attribution-Non Commercial 3.0 Creative commons license. Readers are allowed to copy, distribute and communicate article's contents, provided the author's and Journal of Industrial Engineering and Management's names are included. It must not be used for commercial purposes. To see the complete license contents, please visit http://creativecommons.org/licenses/by-nc/3.0/. 